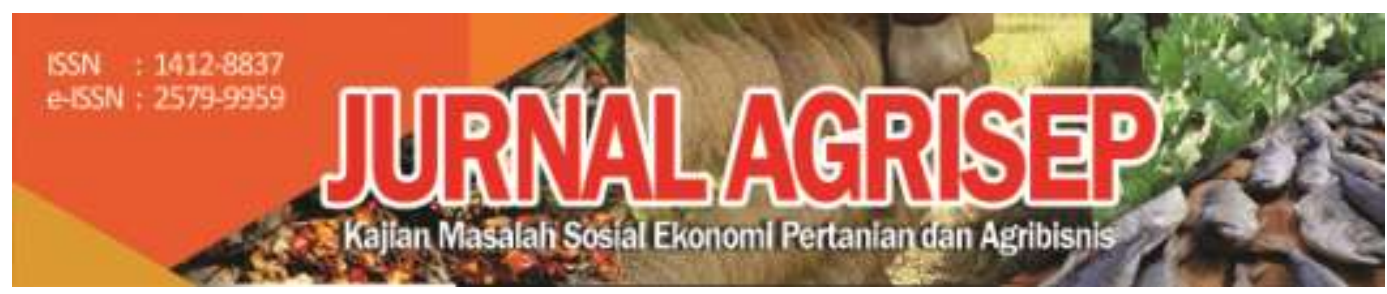

DOI: 10.31186/jagrisep.18.2.343-358

\title{
SERTIFIKASI MINYAK SAWIT PETANI: DAMPAK TERHADAP PEMBANGUNAN DAN PENGHIDUPAN BERKELANJUTAN
}

\section{Smallholders' Palm Oil Certification: The Impact On Sustainable Development And Livelihood}

\author{
Diana Chalil ${ }^{\mathbb{1}_{1}}$; Shaufique F. Sidique ${ }^{2}$; Riantri Barus') \\ ${ }^{1)}$ Faculty of Agriculture, Universitas Sumatera Utara, Indonesia \\ 2)Faculty of Economics and Manajement, University Putra Malaysia, \\ Malaysia \\ Email: diana3@usu.ac.id
}

\begin{abstract}
Sustainable palm oil certification is expected to lead to sustainable development and livelihood. This study was conducted through 240 and 176 certified and noncertified oil palm smallholders in Indonesia and Malaysia, respectively. The data were collected using the clustered convenience sampling method and analyzed with compare means test. The results show that certified smallholders have a superior perception and implementation of a sustainable economic and social environment, enjoy higher productivity and selling prices, are able to maintain the quality of natural resources, are more resistant to production and price fluctuations, and are more prepared for replanting.
\end{abstract}

Keywords: palm oil, sustainable, Indonesia, Malaysia, smallholders

\begin{abstract}
ABSTRAK
Sertifikasi berkelanjutan diharapkan dapat mendukung pengembangan yang berkelanjutan dan peningkatan kesejahteraan pekebun sawit. Dugaan ini diuji melalui 240 sampel di Indonesia dan 176 pekebun sawit sampel yang telah dan belum tersertifikasi di Indonesia dan Malaysia. Data dikumpulkan dengan metode clustered convenience sampling dan dianalisis dengan uji beda rata-rata. Hasilnya menunjukkan bahwa pekebun yang telah tersertifikasi mempunyai persepsi dan implementasi yang lebih baik mengenai lingkungan, ekonomi dan sosial yang berkelanjutan. Mereka juga menikmati produktivitas dan harga jual yang kebih tinggi, lebih menjaga kualitas
\end{abstract}


sumberdaya alam, lebih resisten dalam menghadapi fluktuasi produksi dan harga jual, dan lebih siap dalam menghadapi peremajaan.

Kata kunci: kelapa sawit, berkelanjutan, Indonesia, Malaysia, pekebun

\section{INTRODUCTION}

Palm Oil is one of the important and much debated commodities in the global market. The significant increase in oil palm plantation area has caused high concern on the possible negative impacts on the environment. From 2007 until 2014 oil palm plantations in Indonesia and Malaysia increased by 4.34 million ha and 1.09 million ha or $65.72 \%$ and $25.40 \%$, respectively. With such a large increase, some of the oil palm plantation areas require forest clearing. It also needs a lot of chemical fertilizers usage, thus lead to increased concerns on the negative impact on soil and water quality. On the other hand, the palm oil industry growth provides significant positive economic impact for the producer countries. In 2014, foreign exchange generated from palm oil industry in Indonesia and Malaysia are US\$10.97 billion and US\$15.60 billion, respectively (Directorate General of Estate Crops, 2014; MPOB, 2015). Previous studies show that oil palm smallholders' incomes are higher than other commodities smallholders, and the regional development of districts with oil palm plantations are also faster than other districts (Zakiah \& Ananto, 2013). This shows the trade-off between environmental and economic interests, although in the long run, they might not contradict. A decrease in soil and water conditions would decrease the palm oil productivity, which at the end leads to an increase in profit. Conversely, producers will not be able to incur additional costs to maintain the soil and water quality without additional revenues. This means maintaining sustainable environment is needed to maintain sustainable development and livelihood, and vice versa. Therefore, principles and criteria $(\mathrm{P} \& \mathrm{C})$ of sustainable certification could not only focus in environmental aspects, but also social and economic aspects. An economically sustainable system must be able to produce goods and services on a continuing basis, to maintain manageable levels of government and external debt, and to avoid extreme sectoral imbalances which damage agricultural or industrial production. An environmentally sustainable system must maintain a stable resource base, avoiding over-exploitation of renewable resource systems or environmental sink functions, and depleting non-renewable resources only to the extent that investment is made in adequate substitutes. This includes maintenance of biodiversity, atmospheric stability, and other ecosystem functions not ordinarily classed as economic resources. A socially sustainable system must achieve fairness in distribution and opportunity, adequate provision of social services including health and education, gender equity, and political accountability and participation (Harris, 2003). 
In other words, a certification of sustainability can be used as a tool to improve sustainable development and livelihood. In the context of palm oil, Rountable Sustainable Palm Oil (RSPO) is broadly known and accepted as a complete sustainable certification which covers every environment, economic, and social aspects. In addition, it has also developed a specific P\&C for smallholder certification. Therefore, this study used RSPO certification to test the impact of smallholder certification on sustainable development and livelihood.

\section{Review}

\section{Sustainable Development and Livelihood}

Sustainable is understood as the endurance of a process. From the point of view of neo-classical economic theory, sustainability can be defined in terms of the maximization of welfare over time. Using time discounting as a method of comparing the economic values in different time periods, sustainability is interpreted as an efficient resource allocation. This involves the opportunity costs concept that compares the benefit and loss of the resource allocations. Endurance of the process also means that the process can cope and recover from stresses and maintain or enhance its capabilities, assets, and activities both now and in the future, while not undermining the natural resource base. Livelihood assets include human capital, social capital, natural capital, physical capital and financial capital (Serrat, 2008). Sustainable development and livelihood could only be realized if all of these aspects fulfilled.

\section{Certification and Sustainable Development and Livelihood}

Certification can be seen as a form of non-commercial innovations, as many of its PnC are still new for many smallholders (Chalil, 2013). According to Roger (1995, in Jacobsen 1998) there are five stages of change in the adoption of innovation namely (1) the change in knowledge, (2) persuasion, (3) decision, (4) implementation and (5) confirmation. In the persuasion stage someone already has the attitude and perception about the innovations, which then influence him/her to implement the innovations or not. The impact might only be temporary or sustainably improves the regional development or smallholders' and community livelihood.

Bacon et al. (2008) show that certification for Nicaragua coffee farmers has improve education access, infrastructure investment and monetary saving, but livelihood insecurities such as low income, high emigration and food insecurity still persisted among all small scale producers. Therefore, the existing commitment among the government, coffee industry and producers organizations need to be renewed. The government needs to provide basic social services, the coffee industry need to increases prices and investment, 
while producer organizations need to improve transparency, accountability and efficiency.

For palm oil certification in Indonesia and Malaysia, smallholders receive higher yields, better technical skills and knowledge, higher chances of attracting international funding, and strengthened social relations within the community (Donough, et al., 2009; Beuningen \& Knorringa, 2009; Mollenar et al., 2010). In addition, smallholders' participation on certification contributes positively on their organizations especially on building business relationships, social and human capital, provides additional income generation and livelihood improvement, incorporates stronger supply chain cooperation which lowers production costs, raises productivity, better quality, and stabilization of supply. This can potentially give development opportunities especially to rural regions. In addition, certification has potential ecological benefits which include prevention of deforestation, reduction of greenhouse gas emissions and the preservation of biodiversity (Hidayat et al., 2015; Brandi et al., 2013). Smallholders also receive various indirect benefits, which includes positive health effects due to increased awareness on risks of pesticides and other chemical. Furthermore, roads and other infrastructure improvements have provided farmers better opportunities to reach the mills that also made their daily working practices from and to the fields easier. Nesadurai (2013) suggested that certification gives the local communities an opportunity of having their grievances heard and a chance of re-addressing their complaints.

However, Schoonhover and Speijer (2012) show that sustainable livelihood could be reached if farmers' institution is transparent and efficient. They compare 2 cooperatives in Kenya, which both are certified, have higher yields and higher prices. Cooperation in the region with good local market opportunities is less transparent and less efficient. Extra benefit from higher yield and higher price are mostly enjoyed by management staff, thus does not significantly reduce farmers' vulnerability. In contrast, the more transparent and efficient cooperation gets farmers trust and loyalty and increase their participation in collective actions such as in selling outputs or distributing inputs and tools. This improves their ability to manage costs, access to credit markets, withstand with seasonal shocks and bad years of production, thus maintaining a sustainable livelihood. Cesario (2012) recommends that restructuring and enhancing the certified cooperation financial planning could improve farmers' long term sustainable livelihood development. In some palm oil cases, certification could also insufficient to maintain the sustainable development and livelihood because of its expensive costs, and thus exclude many smallholders from the sustainable palm oil market (Colchester \& Chao, 2011). 


\section{METHOD}

To test the impact of certification on sustainable development and livelihood, this research was conducted in Indonesia and Malaysia, which are the main palm oil producers in the world. Data are collected from certified smallholders, in progress to be certified and non-certified smallholders. In Indonesia, smallholder groups are located in Sei Lilin, Musi Banyuasin District, South Sumatra Province and Ukui, Pelelawan District, Riau Province with a total number of 228 smallholder samples. In Malaysia smallholder groups are located in Sebauh, Lavang Land District, Bintulu, Sarawak (Keresa) and Telupid, Beluran District, Sandakan, Sabah (Sapi) with a total number of 176 smallholder samples.

Sustainable development and livelihood are measured by the impact of certification on smallholders' perception and implementation on environment, economic and social aspects. Environment data cover best management practices, such fertilizer and pesticide applications. Economic data include production, selling price, cost of production, income and household expenditure, while social data cover the application of personal protection equipment (PPE) and land legacy. The impact is analyzed descriptively from the difference between certified smallholders and to-be certified or noncertified smallholders' perception and implementation average, minimum and maximum scores. Perception is mostly measured with qualitative data, which is the percentage of agree statements related to environment, economy and social impact of the certification. Implementation is mostly measured with quantitative data and further tested with compare means independent samples t-test. The change in perception is only analyzed in Malaysia, while the implementation is analyzed both in Indonesia and Malaysia.

\section{RESULTS}

RSPO certification supports sustainability, which covers environment, economy and social aspects. The impact can be seen from the change in smallholders' perception and implementation, which at the end is expected to lead to a sustainable development and livelihood. Details are as follows.

\section{Environment Impact}

The change in environment perception and implementation can be seen in the change of best practice management (BPM) in all cases in Malaysia and Indonesia. The results show that certified smallholders in Keresa have better perception about the impact of their farm practices to environment quality than those of the non-certified. Most of them believe that after implementing the certification PnC, environment quality (86.36\% of the total samples), soil fertility $(72.73 \%)$, waste management $(90.91 \%)$, water and air quality $(63.64 \%$ 
and $77.27 \%$ ), land conservation $(81.82 \%)$ and reforestation $(77.27 \%)$ will be improved. This is even stronger among both the certified and waiting to be certified smallholders in Sapi. The result suggests that all certified smallholders agree that RSPO certification program will improve their waste management practices, hence, reduce air and water pollution. Furthermore, $100 \%$ of the certified smallholders agree that being certified will help them to better conserve their lands and reduce deforestation. This might stem from the improvement in their best management practices, which can be seen in the pollution reduce, responsible waste management, water maintenance, and environmentally friendly herbicides application. In fact, most of the practices are not new for those smallholders that can be seen by the relatively high percentage of implementation among the non-certified smallholders, both in Keresa and Sapi. Only 1 out of 10 best practice management components, which is the reduction in pollution, shows significant difference percentage between the certified and non-certified smallholders. The only management practice that has not been optimally implemented is the replanting of forest trees, with only $57.14 \%$ of adoption among the certified smallholders in Keresa and $12.12 \%$ among non-certified in Sapi.

Similar condition appears in Indonesia. Most of the BMPs are not new for the smallholders. However, with the written Standard Operating Procedure (SOP) and internal control from monitoring unit, the implementation becomes more consistent. Besides internal control, smallholders also receive support from the partner company staff. For example, a significant change can be seen in the harvesting method. Before certification, smallholders use oil palm color as the harvesting criteria, but after certification, they use the number of FFB fall. In accordance to the mill, such a change is likely to improve the oil content.

The other change is in the fertilizer and pesticides applications. Certified smallholders utilize owls as natural enemies for rats to reduce the chemist pesticides usage. For the certified smallholders, all of the fertilizer and pesticide management from planning, purchasing and applications, are conducted through the smallholders' group, to ensure the consistent implementation. The special team members may come from the certified smallholders and their family or paid labors, and coached by technical assistants from Partner Company. Fertilizers and herbicides are purchased collectively through cooperatives or company partner to ensure the usage of non-paraquat herbicides and reduce average costs.

In oil palm plantations the source of greenhouse emissions stems from the nitrogen fertilizers usage, and become the main concern regarding GHG emission issues, soil and water quality (Weng, 2005). Comparing fertilizer usage among all vegetable oil crops, palm oil appears to be the lowest (Rival \& Levang, 2014). However, with huge plantation areas, the needs for fertilizer cannot be supplied by organic one. For example, in Indonesia, the average 
usage per hectare per year is $1,012 \mathrm{~kg}$ or 11.09 million ton per year for the total 10.9 million ha of oil palm plantation areas. In fact, fertilizer usage significantly influences the productivity of palm oil and other vegetable oils crop. Therefore, to balance productivity and environmental quality, fertilizer usage needs to be based on the leaf test recommendation. Higher amounts of fertilizer application, as long as it does not exceed the optimal application amount, would increase tree productivity. Nevertheless, the increase in the amounts of fertilizer would also increase farm expenditure. To maintain a balance between environmental and economic sustainability, fertilizers and pesticides need to be applied in right amount, thus give the optimal fertilizers/productivity and herbicides/productivity ratios.

Certified smallholders in Keresa and Sapi utilizes higher amounts of fertilizer which lead to a slightly higher productivity. Both companies have lower yield/fertilizer ratio than those that are non-certified, although both Sei Lilin and Ukui yielded the opposite results. In Ukui, the increase in productivity for certified plantations are not significant, leading to a lower yield/fertilizer ratio than non-certified smallholders. Details can be seen in Table 1.

Table 1. Ratio of yield and fertilizer of certified and non-certified smallholders

\begin{tabular}{|c|c|c|c|c|c|c|c|c|}
\hline \multirow{3}{*}{ Description } & \multicolumn{4}{|c|}{ Malaysia } & \multicolumn{4}{c|}{ Indonesia } \\
\cline { 2 - 9 } & \multicolumn{2}{|c|}{ Keresa } & \multicolumn{2}{c|}{ Sapi } & \multicolumn{2}{c|}{ Sei Lilin } & \multicolumn{2}{c|}{ Ukui } \\
\cline { 2 - 9 } & C & NC & C & NC & C & NC & C & NC \\
\hline Yield/Fertilizer & 0.04 & 0.05 & 0.03 & 0.04 & 0.05 & 0.16 & 0.03 & 0.04 \\
\hline
\end{tabular}

$\mathrm{C}=$ certified and $\mathrm{NC}=$ non certified

Table 2 shows that in general, fertilizer usage among non-certified smallholders in Malaysia and Indonesia are still lower than their certified counterparts. However, the difference in Keresa and Sapi, both being Malaysian plantations, is insignificant. In Indonesia, nitrogen fertilizer is obtained from Urea and ZA. There are significant differences in the usage of these fertilizers between certified and non-certified smallholders in Sei Lilin and Ukui. Most non-certified smallholders use less fertilizer with a wider range of amount because they produce less capital. For certified smallholders, savings for fertilizers and herbicides are managed by their group; costs are directly subtracted from their sales revenue. Therefore, certified smallholders can apply fertilizer in accordance with the recommended amount and time. 
Table 2. Compare means test of fertilizer usage between certified and noncertified smallholders

\begin{tabular}{|c|c|c|c|c|c|c|c|}
\hline \multirow{4}{*}{ Description } & \multirow{4}{*}{ Unit } & \multicolumn{6}{|c|}{ Malaysia } \\
\hline & & \multicolumn{3}{|c|}{ Keresa } & \multicolumn{3}{|c|}{ Sapi } \\
\hline & & Means & & $\begin{array}{l}\mathrm{t}- \\
\text { stat }\end{array}$ & Means & & $\begin{array}{l}\text { t- } \\
\text { stat }\end{array}$ \\
\hline & & $\mathrm{C}$ & $\mathrm{NC}$ & & $\mathrm{C}$ & $\mathrm{NC}$ & \\
\hline \multirow[t]{3}{*}{$\begin{array}{l}\text { Fertilizer } \\
\text { usage }\end{array}$} & $\mathrm{Kg} / \mathrm{ha}$ & 197 & 161 & 1.23 & 397.7 & $\begin{array}{c}205.80 \\
- \\
297.30\end{array}$ & 0.98 \\
\hline & & \multicolumn{6}{|c|}{ Indonesia } \\
\hline & & \multicolumn{3}{|c|}{ Sei lilin } & \multicolumn{3}{|c|}{ Ukui } \\
\hline Urea usage & $\mathrm{Kg} / \mathrm{ha} / \mathrm{sem}$ & 157.46 & 43.53 & & & & \\
\hline ZA usage & & & & & 171.01 & 82.45 & \\
\hline $\begin{array}{l}\text { Nitrogen } \\
\text { usage }\end{array}$ & $\mathrm{Kg} / \mathrm{ha} / \mathrm{sem}$ & 72.43 & 20.02 & 9.79 & 35.91 & 17.31 & 8.83 \\
\hline
\end{tabular}

The average herbicides usage among certified smallholders is more uniform, both in types and amount. Prior to certification, some smallholders have not implemented green weed killing and use total spraying method that kills all weeds by using paraquat such as Gramoxone. After the certification they use selective spraying by using Metil Metsulfuron (Ally) for broadleaf and Glifosat (Roundup) for narrow leaf weeds and no longer use any types of paraquat.

In Malaysia, with a larger average land area (6.64 ha and 3.49 ha for certified and uncertified smallholders, respectively), smallholders have more capital to buy inputs. Non-certified smallholders in Keresa use significantly more herbicide than the certified. This is caused by a lack of information and knowledge, with the average herbicide application being 13.82 liter and 6.64 liter, respectively with $-3.35 \mathrm{t}$-stat. In addition, the range of non-certified herbicide usage is also greater, indicating that the application is not based on recommendation. Low amount of herbicide application by certified smallholders could be partly caused by practical information earned from training programs provided by the Keresa sustainability team. Similar results can be seen in Sapi, in which the annual herbicide application of the certified and waiting-to-be certified farmers herbicides applications are lower than the average of non-certified farmers, with an average of 7.30-8.40 liters and 13.60 liters, respectively and t-stat -3.51 . 
In Indonesia, non-certified smallholders also have larger land area, which are 2.52 and 2.03 ha, respectively. However, most of the certified smallholders also have additional non-certified oil palm area. Comparing to those in Malaysia, on average non-certified land area in Indonesia is lower, indicating their lower capital to buy inputs and use paid labor. Therefore, around $80 \%$ of the non-certified smallholders use family labor and $22.50 \%$ manually clear the weeds using family labor. On average, certified smallholders in Sei Lilin use more herbicide than those of the non-certified, which are 1.22 litre/ha and 0.73 litre/ha, respectively with $2.83 \mathrm{t}$-stat. However this is unlikely reflecting their understanding about the green weed method, as those who use chemical spray still use total spraying with Gramoxone. In Ukui, certified smallholders do not know the amount of herbicide use in their land, as the whole process is managed by the partner company. In other words, while in Sei Lilin smallholders are involved in the process, hence knowledge transfer occur, smallholders in Ukui only involve in the implementation, thus no transfer knowledge and their roles are almost similar with paid workers.

Finally, storing agricultural chemicals correctly is also as equally important as handling the chemicals. In Malaysia the percentages of smallholders with herbicide and fertilizer storage facilities are higher among the certified ones, but the percentage is lower for pesticide storage. Some smallholders do not have designated stores for agricultural inputs as they only buy inputs in small quantity for one-off application. This can be seen in most pesticide storage facilities in Keresa for both certified and non-certified smallholders, with $78.57 \%$ and $77.08 \%$ samples having

In Sei Lilin, certified smallholdings carry out fertilization and spraying by a special team and are stored in the cooperative warehouse. In Ukui fertilizers are applied by smallholders but are purchased and stored by cooperative, while herbicides are applied by a special team that is coordinated by the partner company and stored in the company warehouse. For non-certified smallholders, both in Sei Lilin and Ukui fertilizers and herbicides are bought for one application, therefore they do not need any storing facilities. If there is an excess, then fertilizers or herbicides are only stored at their backyard. Both in Sei Lilin and Ukui, used containers are returned by the spraying team to the partner company office area. Differently, non-certified smallholders have a number of ways to treat the used containers. Some dump the containers in the their plantation area to avoid air pollution from burning, but some still burn the containers, as this is easier, and does not need extra work and time. A few smallholders even reuse the containers for carrying water to their plantations, or sell them. However, some non-certified smallholders who also have noncertified plantations also return the containers to partner company through cooperative. 


\section{Economic Impact}

Survey results show that economic perceptions among smallholders in Keresa and Sapi are different. In Keresa, there is a clear distinction between certified and non-certified smallholders. Only few of the non-certified share positive opinions of the certified smallholders. Most of them have remained skeptical on the economic impacts resulting from certification, as they have little or no experience of adopting sustainability principles. For example, more than $70 \%$ of the total certified smallholders think that having higher Fresh Fruit Bunches (FFB) benefits productivity and quality, and receive premium price, while only less than $35 \%$ of the non-certified smallholders have the same positive opinion. However, only few smallholders in both the certified and non-certified have a positive perception about the improvement in their household assets, expenditure and credit facilities, with a range of percentage $36.36 \%$ to $54.55 \%$ and $10.53 \%$ and $21.05 \%$, respectively. Differently, certified and non-certified smallholders' economic perceptions in Sapi are not significantly different, although both show better perception than those in Keresa in all components of the economic perceptions. Even in access to credit facilities the non-certified smallholders have slightly higher perception than the certified group, with $40.91 \%$ and $48.84 \%$ positive opinions, respectively.

The change in economy perception and expectation is likely influenced by the impact in economy aspects, including production, selling price, cost of production, income and household expenditure. Besides tree ages, fertilizers and pesticides are inputs that significantly influence the oil palm tree productivity. In general, certified smallholders in Keresa achieved higher yields than non-certified in both tree age categories. The most significant difference is in the 3-6 year old tree category, while in the 7-20 year old tree category, the difference is only marginal. However, both show significant compare means results. The difference in yield of the young mature category can be largely attributed to the extension support to certified smallholders. This is a critical stage of growth for the trees and the extension services provided improved the way these trees are managed. However, poor yield for the old trees of noncertified smallholders is mostly due to high tree density, which exceeded the optimal capacity of having 136 trees per hectare. The details can be seen in Table 3.

Table 3. Certified and non-certified smallholdings' yield based on crop age in Malaysia

\begin{tabular}{|c|c|c|c|c|c|c|}
\hline \multirow{2}{*}{$\begin{array}{c}\text { Crop age } \\
(\text { Year) }\end{array}$} & \multicolumn{5}{|c|}{ Yeresa } & \multicolumn{3}{c|}{ Sapi } \\
\cline { 2 - 7 } & $\mathrm{C}$ & $\mathrm{NC}$ & t-stat & $\mathrm{C}$ & NC & t-stat \\
\hline $3-6$ & 15.13 & 8.17 & 2.848 & 8.22 & 13.14 & -0.67 \\
\hline $7-20$ & 8.83 & 8.34 & 1.58 & 11.56 & 12.11 & 0.68 \\
\hline
\end{tabular}

352 | Diana Chalil; Shaufique F. Sidique; Riantri Barus; Smallholders' ... 


\begin{tabular}{|l|l|l|l|l|l|l|}
\hline & 20 & & & 7.47 & 16.74 & -0.78 \\
\hline
\end{tabular}

However, in Sapi certified smallholders do not perform better, indicating their lack of technical knowledge and capacity on fertilization. On the recommendation of salesperson, they used uncommon types of fertilizer that are different from industry recommendations. They received inadequate extension service. Their group organizer also lacked agronomic expertise and focused more on preparing smallholders towards certification. On average certified smallholders have lower productivity than the non-certified at all crop age (Table 3). Results also show that on average, smallholdings past their prime age trees have the highest average yield compared to the yields of prime and young trees. This is in contrast to the normal yield curve of oil palm wherein trees on their prime age have higher yields compared to trees past their prime. The downward trend of palm oil prices towards the end of 2008 due to world financial crisis resulted to the neglect of many oil palm trees especially the older ones. Application of fertilizer was very limited and trees were left untended. However, things made a turn when CPO prices started to pick up, reaching levels above $\$ 1,000$ per tonne in 2011 and 2012 (Sime Darby, 2013). Smallholders then began nurturing their plots again and older trees which used to bear less fruits became more productive, thus they have slightly higher yields compared to prime age palm trees.

Table 4 shows that in Sei Lilin, Indonesia the average productivity of certified smallholding is higher than the non-certified. With various plant managements the range of non-certified smallholders' productivity is wider than those of the certified,. Similarly, in Ukui, Indonesia the average productivity of certified smallholders is also higher than the non-certified. However, not only the non-certified smallholders, certified smallholders also have wide range of productivity, which are 1,000-2,000 kg/ha/semester and $1,274-2000 \mathrm{~kg} / \mathrm{ha} /$ semester, respectively.

Table 4. Certified and non-certified yield in Indonesia

\begin{tabular}{|c|c|c|c|c|c|}
\hline \multicolumn{6}{|c|}{ Yield (kg/ha/sem) } \\
\hline \multicolumn{3}{|c|}{ Sei Lilin } & \multicolumn{3}{c|}{ Ukui } \\
\hline C & NC & t-stat & C & NC & t-stat \\
\hline $6,994.93$ & $3,277.14$ & -8.54 & $4,662.00$ & $3,117.50$ & -3.77 \\
\hline
\end{tabular}

In addition to production fluctuations, oil palm smallholders also have to deal with price fluctuations. However, for certified smallholders that have been assisted for plant maintenance and harvest, partner-company appears to continuously buy with relatively stable prices. In Indonesia, certified smallholders receive at least the same price with the province government biweekly determined price (Disbun price). The price are different for each age group, which are lower for FFB produced by old trees. In general, Disbun price 
within the same age group is higher than market price. However, during the survey $97 \%$ of the certified smallholder samples in Sei Lilin have old trees (above 20 years), while those of the non-certified only 2,5\%. Therefore, on average certified smallholders receive lower price than the non-certified, which are IDR1,466 (RM0.45) and IDR1,474.38 (RM0.45) per $\mathrm{kg}$, respectively. However, even in such a condition, the difference is relatively small and not significant with $0,35 \mathrm{t}$-stat. In addition, with private company partnership that is directly integrated with global market, besides the normal Disbun price, certified smallholders also receive premium price from global trade. In Ukui, most certified smallholder crop ages are still below 20 years, thus receive significantly higher price than those the non-certifed, which are IDR1,694.06 (RM0.52) and IDR1,474.38 (RM0.45) per kg, respectively with $-4.53 \mathrm{t}$-stat.

The impact of certification could also be seen in the improvement of production costs. Certified smallholders could decrease their production costs by the improvement in their knowledge and management. The former leads to an increase in the improvement in their input usage efficiency, while the latter decrease their input buying price through collective purchase. Table 5 shows that in Keresa, Malaysia certified smallholders have lower annual farm expenditure per hectare than the non-certified ones. This is mainly related to the improvement of certified smallholders' knowledge and ability to make informed fertilization decisions. In addition, certified smallholders received and applied fertilizers that were ordered in bulk, thus they have adequate feed for their trees at a price lower than the retail level. Similarly, in Sapi, Malaysia certified smallholders also have lower annual farm expenditure than the noncertified However, the lower expenditure among certified smallholders is not directly attributed to more efficient use of resources. Some of them still maintain buying cheaper low quality inputs, which have little impact on productivity. On average, in Sei Lilin, Indonesia, certified smallholders' production costs per ha is higher than the non-certified, as they use more inputs as recommended. However, with higher inputs, certified smallholders enjoy higher productivity. Moreover, the inputs are collectively bought, thus could be purchased with lower price. As a result, non-certified smallholders' average cost per kg FFB is higher than the certified. Fertilizer cost appears to be the highest proportion, which is $42.05 \%$ of the total cost, while that of the herbicide is $15.14 \%$. Similar condition appear in Ukui, in which certified smallholder productivity is also higher than the non-certified, thus their average cost per $\mathrm{kg}$ FFB is lower.

354 | Diana Chalil; Shaufique F. Sidique; Riantri Barus; Smallholders' ... 
Table 5. Cost of production of the certified and non-certified smallholders in Malaysia and Indonesia

\begin{tabular}{|c|c|c|c|c|c|c|}
\hline \multirow{3}{*}{ Description } & $\mathrm{C}$ & $\mathrm{NC}$ & tstat & $\mathrm{C}$ & $\mathrm{NC}$ & tstat \\
\hline & \multicolumn{6}{|c|}{ Malaysia } \\
\hline & \multicolumn{3}{|c|}{ Keresa } & \multicolumn{3}{|c|}{ Sapi } \\
\hline \multirow[t]{3}{*}{$\begin{array}{l}\text { Total production cost } \\
\text { (RM/ha/year) }\end{array}$} & 1,025 & 1,289 & -0.97 & 1,130 & 1,416 & 0,42 \\
\hline & \multicolumn{6}{|c|}{ Indonesia } \\
\hline & \multicolumn{3}{|c|}{ Sei Lilin } & \multicolumn{3}{|c|}{ Ukui } \\
\hline $\begin{array}{l}\text { Total production } \\
\text { (RM/ha/year) }\end{array}$ & 784.44 & 376.62 & & 530.81 & 385.76 & \\
\hline $\begin{array}{lll}\begin{array}{l}\text { Average } \\
(\mathrm{RM} / \mathrm{kg})\end{array} & \text { production } & \text { cost } \\
\end{array}$ & 0.12 & 0.22 & 2.79 & 0.13 & 0.17 & 2.46 \\
\hline
\end{tabular}

RM = Ringgit Malaysia

The improvement in production, selling price and cost of production leads to the improvement in certified smallholders' income. As smallholders in Keresa are isolated from the nearest town, they rely entirely on oil palm. Household members have very little opportunity to work in other employment and the number of household members has insignificant effect on their annual household income. Thus, it would not be overly biased to compare total household income among the respondents without controlling for the household size. Annual household income of certified smallholders in Keresa is higher than the non-certified, which are RM23,922 and RM20,484, respectively with $0.88 \mathrm{t}$-stat. Such a difference is characterized by their farm size, yield, and FFB price. The certified smallholders operated on a larger scale and produced higher yield. They also enjoyed fair FFB prices in comparison to those received by non-RSPO members from private traders or mills. Although the fair offer is unexclusive for the certified population, most non-certified smallholders prefer to sell to private traders or mills due to cash terms of trade and also because of the distance.

Most $(81.25 \%)$ of the certified smallholder samples feel that their annual household income has increased after certification. Although the change can be partly affected by the biological age of their trees, most of them believed that BMP of the certification underpinned their farm work more systematically and sensibly. This follows by the improvement of the smallholder per capita household expenditure, which can be seen as an indication of the improvement of their livelihood. The certified per capita household expenditure is higher 
than those that are not certified, which are RM3,994 and RM2,794, respectively with $1.652 \mathrm{t}$-stat. With limited access to credit facility, smallholders in Keresa are only able to spend within their earning capacity.

Similarly, the majority of smallholders in Sapi rely on their own oil palm plots for their livelihoods. Most households also have single income-earners as work opportunities are limited in the area. Certified smallholders have the highest income (RM28,834), followed by waiting-to-be certified (RM28,072) and non-certified smallholders (RM26,123), with $0.25 \mathrm{t}$-stat. The incomes of certified and waiting to be certified respondents are higher than non-certified respondents despite the non-certified ones having the highest yield. Most certified members enjoy the benefit of proximity of their oil palm plots to the mill, enabling them to deliver their harvests directly to the mill which employed a fair pricing and grading mechanism following MPOB standard. They receive their payment a month after the delivery. On the other hand, majority of non-certified smallholders are located in inner areas distant from the mill. Their crops are sold to traders who generally offer discounted prices after factoring in the transportation cost. Such discounts, however, are not done in a transparent a manner. Some non-members also prefer selling their FFBs to traders for instant cash. This implies that certification does not equate to higher yields and higher yields do not necessarily translate to higher incomes. However, appropriate technical support and extension services on oil palm production and efficient market access can help drive higher production or revenues among different categories of smallholders. $76.19 \%$ of the certified smallholders in Sapi believe their income has improved after the certification.

Unlike certified smallholders in Keresa, those in Sapi have an annual per capita expenditure lower than the non-certified, which are RM2,799 and RM3,921, respectively. As previously mentioned, many smallholders misallocate resources which are perceived to be cheaper but not necessarily beneficial. One possible reason also for the reduced expenditures among certified smallholders is their proximity to the mill and town centers which reduces overall transportation costs. Generally, inputs and household needs are relatively cheaper in areas proximate to their source.

In Sei Lilin Indonesia, although certified smallholders utilize old crops and lower selling price, their average income is higher than the non-certified, which are IDR7.584.865 (RM2,331.48) and IDR3.599.232 (RM1,106.35) per ha per semester, respectively with -6.72 of t-statistics. In Ukui, certified smallholders' average income is also higher than the non-certified, which are IDR6,231,329.85 (RM1,915.42) per ha per semester and IDR3,707,731.37 (RM1,139.70) per ha per semester, respectively with 4.05 t-stat.

The other aspect that is important to maintain their improvement is the preparation for replanting program. In Indonesia, certified smallholders save some of their sales revenue for replanting through group management. In Sei 
Lilin, this saving has started in 2013 with $5 \%$ - 10\% cut of their total sales revenue per month. This means saving will be big during the good harvest, and vice versa. However, in Ukui, some certified smallholder groups have not managed such saving because their average crop age is still 19 years. Only $23.19 \%$ of them started saving, which amount varies between IDR30,000 (RM9.22) - to IDR200,000 (RM61.48) per month, although at the end of the economic age this is still not enough to cover the estimated replanting investment, which is about IDR50-60 million (RM15,369.29 - RM18,443.15). Most (88.5\%) non-certified smallholders have not started to save for replanting. Others stated that their income is not enough to save, thus expect to receive some loans for replanting.

\section{Social Impact}

After receiving benefits from certification, smallholders in Keresa believe that RSPO certification generally improves their social wellbeing. This can be seen from the significant change between the percentage positive responses compare to the non-certified with general index mean 0.66 and 0.10 , respectively. Such perception is underpinned by their experience in relation to their improved association with smallholders and millers, acquisition of best management practices, knowledge to realize environmentally friendly farming activities, and enhanced standard of living through access to public amenities (i.e. road, healthcare, and education). Similarly, certified and waiting-to-be certified smallholders in Sapi strongly agree that RSPO certification brings social benefits to the community. However, the waiting-to-be certified ones are likely to have slightly higher perception than the certified, as indicating by their mean index 0.915 and 0.884 , respectively. This is mainly explained by the improvement in their food security. Most non-certified farmers are located in remote areas whereas certified members are located in main roads, thus, perceived lower level of improvement in food security as they had good access to different sources of food like markets and restaurants even prior to certification.

The smallholders' perception on their health improvement after certification is partly explained by the improvement in the personal protective equipment (PPE) use during the application of agricultural chemicals such as fertilizers and herbicide. PPE consists of gloves, coverall, apron, safety boots, head cover, goggles and protective mask. The results show that certified smallholders are slightly more protected when applying fertilizers and herbicides than the non-certified. However, the PPE indices for both certified and non-certified smallholders in Keresa are still very low. With maximum index 7, on average they only have about 2 PPE index. Differently, certified and non-certified smallholders in Sapi have better practices, showing by their PPE index that are 6.09 and 4.53, respectively. Protective gloves and masks are the 
two most important PPE worn by the farmers when applying fertilizers and herbicides, which over time will protect smallholders to various health problems due to skin contact and mist inhalation of chemicals.

In Indonesia, the most significant impact of certification can be seen in the change of smallholders' concern for health and safety. Most of the non-certified smallholders do not use protection in the application of fertilizers and pesticides, while most paid workers of certified smallholders' spraying team always wear a mask when doing application of fertilizers and pesticides. Moreover, after fertilizing and spraying the team clean themselves under running water, which facilities are provided at each of the certified smallholder cooperative office. The results show that certified smallholders' awareness for wearing PPE is higher than the non-certified. Significant difference can be seen on smallholders in Sei Lilin, where only $20 \%$ of the non-certified smallholders wear PPE, while all of the certified wear PPE both in fertilization and in spraying. Initially smallholders were reluctant to wear PPE that feels as obstacles in working. The same was found in Ukui, but the difference is relatively small. Some certified smallholders still have not worn PPE, while more than $50 \%$ of all non-certified smallholder wear PPE samples both during fertilizing and spraying.

Running perennial crop business, smallholders need a kind of business assurance to maintain their good efforts for implementing sustainable management. One of the important aspects is the land legality. In accordance to Mohr and Bausch (2013), one of the social sustainability indictor is "no contested land", which provides smallholders a long term business assurance. Land certificates can fulfil the assurance, but head of village or district letter does not have the force of law. In fact, in Indonesia, both the certified and noncertified smallholders appear to have good awareness for this. Except less than $15 \%$ non-certified smallholders in Sei Lilin, all smallholders have their land certificates.

\section{CONCLUSION}

As been mentioned previously, development and livelihood can continue if natural and human resources can be maintained in the long term. In other words, sustainability in economy is highly related with the sustainability in social and environment. Results from 4 cases in Indonesia and Malaysia show that certification has impacts in smallholders' perception and implementation in environment, economic and social aspects. In the short term the impact can be seen in income increase as a result of production, selling price and cost of production improvements. In addition, the short term impact can also be seen in the improvement of smallholding best management practices, thus maintain the quality and quantity of natural resources. Combined with a long term

358 | Diana Chalil; Shaufique F. Sidique; Riantri Barus; Smallholders' ... 
business assurance through land legality, such a condition is expected to sustain the economic development and smallholders' livelihood. 


\section{REFERENCE}

Bacon, C. M., Mendez, V. E., Gomez, M. E. F., Stuart, D. \& Florez, S. R. D., (2008). Are sustainable coffee certifications enough to secure farmer likelihoods? : The millennium development goals and Nicaragua's fair trade cooperatives. Globalizations, 5 (2): 259-274. doi:10.1080/14747730802057688

Brandi, C., Cabani, T., Hosang, C., Schirmbeck, S., Westermann, L., \& Wiese, H. (2013). Sustainability certification in the Indonesian palm oil sector: Benefits and challenges for smallholders. Deutsches Institut für Entwicklungspolitik.

Cesario, S. (2012). Organic cacao farming in Transamazônica: An assessment of sustainable livelihood development. Independent Study Project (ISP) Collection. $\quad$ Paper $1489 . \quad$ Retrieved from http://digitalcollections.sit.edu/isp_collection/1489.

Chalil, D. (2013). Cases on the diffusion and adoption of sustainable development practices. Assessment of smallholders' barriers to adopt sustainable practices (pp. 439-467). USA: IGI Global. doi:10.4018/978-14666-2842-7.ch016.

Colchester, M., \& Chao, S. (2011). Oil palm expansion in South East Asia: An overview. Oil Palm Expansion in South East Asia, 1.

Directorate General of Estate Crops (2014). Tree crop estate statistics of Indonesia: Palm oil 2013-2015.

Donough, C. R., Witt, C., \& Fairhurst, T. H. (2009). Yield intensification in oil palm plantations through best management practice. Better Crops, 93(1): 12-14.

Harris, J. M. (2003). Sustainability and sustainable development. Internet encyclopedia of ecological economics international society for ecological economics. $\quad$ Retrieved from http://isecoeco.org/pdf/susdev.pdf.

Hidayat, N. K., Glasbergen, P., \& Offermans, A. (2015). Sustainability certification and palm oil smallholders' livelihood: A comparison between scheme smallholders and independent smallholders in Indonesia. International Food and Agribusiness Management Review, 18(3): $25-48$.

Jacobsen, D. M. (1998). Adoption patterns and characteristics of faculty who integrate computer technology for teaching and learning in higher education. Doctoral Dissertation. Retrieved from http://people.ucalgary.ca/ dmjacobs/phd /diss/chapter_2.html\#related-contexts.

Mohr, A. \& Bausch, L. (2013). Social sustainability in certification schemes for biofuel production: an explorative analysis against the background of

360 | Diana Chalil; Shaufique F. Sidique; Riantri Barus; Smallholders' ... 
land use constraints in Brazil. Energy, Sustainability and Society. Advance online publication. doi:10.1186/2192-0567-3-6

Nesadurai, H. E. (2013). Food security, the palm oil-land conflict nexus, and sustainability: a governance role for a private multi-stakeholder regime like the RSPO?. The Pacific Review, 26(5): 505-529.

Overview of the Malaysian Oil Palm Industry 2015. Retrieved from http://bepi.mpob.gov.my/images/overview/Overview_of_industry_ 2015.pdf

Rival, A., \& Levang, P. (2014). Palm Oil Controversies: Oil Palm and Development Challenges. Indonesia: CIFOR.

Schoonhoven-Speijer, M. (2012). Maintaining a sustainable livelihood: An analysis of the effect of UTZ certification on market access, risk reduction and livelihood strategies of Kenyan coffee farmers (Master's Thesis). Radbound University Nijmegen, Netherland.

Serrat, O. (2008). The sustainable livelihoods approach. Knowledge solutions 15. Asian Development Bank. Retrieved from www.adb.org/sites/default/files /.../sustainable-livelihoodsapproach.pdf

Van Beuningen, C., \& Knorringa, P. (2009). Inclusive improvement: Standards and smallholders: Taking stock and moving on. Netehrlands: RS Drukkerij.

Weng, C. K. (2005). Best developed practices and sustainable development of the oil palm industry. Journal of Oil Palm Research, 17: 124-135.

Zakiah \& Ananto, E. E. (2013). Kemandirian Pangan Indonesia dalam Perspektif Kebijakan MP3EI. Konflik Kepentingan Usahatani Pangan dan Perkebunan (pp. 543-558). Balitbangtan. Retrieved from www.litbang.pertanian.go.id/buku/kemandirian-panganindonesia/BAB-VIII-3.pdf. 